\title{
JOYCE
}

The Return of the Repressed 



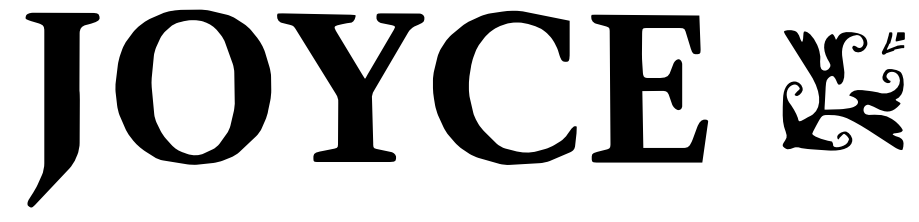

\section{The Return of the Repressed}

Edited by Susan Stanford Friedman

CORNELL UNIVERSITY PRESS, ITHACA AND LONDON 
Open access edition funded by the National Endowment for the Humanities/ Andrew W. Mellon Foundation Humanities Open Book Program.

\section{Copyright (C) 1993 by Cornell University}

"Mothers of Invention/Doaters of Inversion: Narcissan Scenes in Finnegans Wake," by Chrstine Froula, copyright (C) 1993 by Christine Froula.

All rights reserved. Except for brief quotations in a review, this book, or parts thereof, must not be reproduced in any form without permission in writing from the publisher. For information, address Cornell University Press, Sage House, 512 East State Street, Ithaca, New York 14850, or visit our website at cornellpress.cornell.edu.

First published 1993 by Cornell University Press

Library of Congress Cataloging-in-Publication Data

Joyce: the return of the repressed / edited by Susan Stanford Friedman.

p. cm.

Includes bibliographical references and index.

ISBN-13: 978-0-8014-2799-2 (cloth) — ISBN-13: 978-0-8014-8073-7 (pbk.)

1. Joyce, James, 1882-1941-Criticism and interpretation. I. Friedman, Susan Stanford.

PR6019.09Z6693 1993

$823^{\prime} .912-\mathrm{dc} 20 \quad 92-54966$

The text of this book is licensed under a Creative Commons Attribution-NonCommercial-NoDerivatives 4.0 International License: https://creativecommons.org/licenses/by-nc-nd/4.0/ 
For my mother, who loved butterflies Anne Thompson Stanford I 917-I 992 
